\title{
Protection of Right to Environment in International Public Law
}

\author{
Juraj Jankuv \\ Trnava University in Trnava \\ juraj.jankuv@gmail.com
}

JANKUV, Juraj. Protection of Right to Environment in International Public Law. International and Comparative Law Review, 2019, vol. 19, no. 1, pp. 146-171. DOI: 10.2478/iclr-2019-0005

\begin{abstract}
Summary: Substantive human right to environment represents a relatively new element in international human rights catalogues. This human right has gradually become established in international public law since the 1970s. This paper deals with the identification and analysis of the formal sources of two branches (or, according to some opinions, subbranches) of international public law - international environmental law and the international human rights law that enshrine substantive human right to environment as well as with the identification of the relevant international law mechanisms of direct and indirect protection of this right.
\end{abstract}

Keywords: International Public Law, International Environmental Law, International Human Rights Law, environmental human rights, substantive human right to environment, procedural environmental rights.

\section{Foreword}

Existing international public law allows us to identify international documents that enshrine many human environmental rights. One of them is substantive human right to environment, which represents a relatively new element in international human rights catalogues. This human right has gradually become established in international public law since the 1970s, with the mechanisms of its protection developing itself in the interaction of the relevant rules of two branches (or, according to some opinions, subbranches) of international public law - international environmental law and international human rights law. The aim of this contribution is to identify and analyse the formal sources of international environmental law and international human rights law which enshrine substantive human right to environment and to identify the relevant international universal and regional legal mechanisms for the direct and indirect protection of this right. 


\section{Implementation of substantive human right to environment into inter- national environmental law and direct protection of this right}

With an increase of the importance of the status of an individual as one of the subjects of international public law, the individual was first established in international public law as a responsible subject with „passive legal legitimacy“ after World War II, in the context of prosecuting crimes under international law. The first international tribunals acting in order to prosecute those crimes were the International Military Tribunal at Nuremberg and the International Military Tribunal for the Far East at Tokyo. At the present times there are other international tribunals and courts with the similar powers - the International Criminal Tribunal for the former Yugoslavia, the International Criminal Tribunal for Rwanda and the International Criminal Court ${ }^{1}$ and even so called mixed criminal tribunals acting at the national level in different countries with the power to adjudge cases under international public law, as well. ${ }^{2}$

After the Second World War, however, the second level of the active role of an individual at the international scene is developing in the position of the recipient of the rights and freedoms established by international normativity. ${ }^{3}$ An immediate impetus for the development of this active role was the adoption of the Universal Declaration of Human Rights (1948) and, consequently, the adoption of binding conventions guaranteeing human rights and freedoms to all human beings or certain groups of persons. ${ }^{4}$ However, these documents contained only a minimum of human environmental rights. The relatively rapid socio-economic development, especially on the European continent, has led to the gradual expansion and enrichment of human rights catalogues, including human rights of an environmental nature. At present, it is possible to identify total of six purely environmental human rights in international public law. These rights include three substantively understood environmental rights - right to environment, right to water and right to sanitation (e.g. called right to safe environmental health conditions) and three procedural environmental rights - right to access to environmental information, right to participate in environmental decision-making and right to access to legal protection in environmental matters.

The first and crucial step in direction of anchoring environmental human rights was the creation of the concept of substantively understood human right to environment, which is the most widely understood environmental right and

1 ZÁSTĚROVÁ, Jana. Jednotlivci: právo na životní prostředí. In: ŠTURMA, Pavel. a kol. Mezinárodní právo životního prostředí, I. část (obecná). Beroun: IFEC, 2004. p. 36.

2 See POTOČNÝ, Miroslav, ONDŘEJ, Jan. Mezinárodní právo veřejné. Zvláštní část. 6. doplněné a prepracované vydání. Praha: C. H. Beck 2011. pp. 510-511.

3 ZÂSTĚROVÁ, Jana. Jednotlivci: právo na životní prostředí. In: ŠTURMA, Pavel. a kol. Mezinárodní právo životního prostředí, I. část (obecná). Beroun: IFEC, 2004. p. 36.

4 KLUČKA, Ján. Medzinárodné právo verejné (V̌̌eobecná a osobitná čast'). Bratislava: Wolters Kluwer, 2017. pp. 79-80. 
which is the subject of our interest in this article. The first „whistle-blower" indicating the creation of this right was the establishment of two articles of the International Covenant on Economic, Social and Cultural Rights (1966). ${ }^{5}$ Article 11 (1) of this international treaty reads:" The States Parties to the present Covenant recognize the right of everyone to an adequate standard of living for himself and his family, including adequate food, clothing and housing, and to the continuous improvement of living conditions. The States Parties will take appropriate steps to ensure the realization of this right, recognizing to this effect the essential importance of international co-operation based on free consent." The formulation "right of everyone .... to the continuous improvement of li-ving conditions" already indirectly indicates the need to formulate right to environment. Article 12 (1) of the covenant reads: "The States Parties to the present Covenant recognize the right of everyone to the enjoyment of the highest attainable standard of physical and mental health." Article 12 (2b) reads: „The steps to be taken by the States Parties to the present Covenant to achieve the full realization of this right shall include those necessary for: ... (b) The improvement of all aspects of environmental and industrial hygiene." These two provisions indicate the primary existence of human right to sanitation (right to safe hygienic environmental conditions), but its formulation „improvement of all aspects of environmental hygiene "indirectly indicates the need to recognize the existence of the right to environment as well as the similar provision of Article 11 (1) pact.

Scientific discussion on the stabilization of the new human right to environment (further even shortened "right to environment"), understood as substantive right, also in line with the mentioned provisions of the International Covenant on Economic, Social and Cultural Rights (1966), strengthened in the mid-sixties of the twentieth century. ${ }^{6}$ The result of this discussion was the embodying of this right, according to some views of international public law science understood as a basic human right, ${ }^{7}$ into an international document of a fundamental nature for the protection of environment - Declaration of the United Nations Conference on the Human Environment ${ }^{8}$ adopted at the United Nations Conference on the Human Environment, June 5-16, 1972, Stockholm. Principle 1 of this declaration reads: "Man has the fundamental right to freedom, equality and adequate conditions of life, in an environment of a quality that permits a life of dignity and well-being, and he bears a solemn responsibility to protect and improve

5 International Covenant on Economic, Social and Cultural Rights (1966), United Nations, Treaty Series, vol. 993, p. 3.

6 ZÁSTĚROVÁ, Jana. Jednotlivci: právo na životní prostředí. In: ŠTURMA, Pavel. a kol. Mezinárodní právo životního prostředí, I. část (obecná). Beroun: Eva Rozkotová - IFEC, 2004. p. 36.

7 ZÁSTĚROVÁ, Jana. Jednotlivci: právo na životní prostředí. In: ŠTURMA, Pavel. a kol. Mezinárodní právo životního prostředí, I. část (obecná). Beroun: Eva Rozkotová - IFEC, 2004. p. 37.

8 Declaration of the UN Conference on the Human Environment, Stockholm, 5-16 June 1972, UN Doc. A/Conf. 48/14/Rev. 1 (1972) 
the environment for present and future generations.". Coming up from the international public law science opinions, this provision is enshrining substantive right to environment called even substantive right to a healthy environment, ${ }^{9}$ or substantive right to a decent environment. ${ }^{10}$ Title of this right is used in the international public law scientific literature even in the different form as far as the grammar is concerned. Some authors are using the formulation - substantive right to the environment ${ }^{11}$ some of them are using the simplified form - substantive right to environment. ${ }^{12}$ As far as this article is concerned, we will use the title of this right in the form "substantive human right to environment" or its shortened form "right to environment".

The enactment of substantive human right to environment in the Declaration of the Stockholm Conference on the Human Environment (Stockholm declaration) has influenced lately adopted international public law normativity. This right was implemented in various other international instruments and conventions adopted within the framework of the United Nations, conferences organized by the United Nations, international organizations associated to the United Nations as well as conventions and documents international regional organizations.

Almost twenty years after the Stockholm Conference the UN General Assembly recalled the language of the Principle 1 of the Stockholm Declaration in resolution 45/94 (1990) stating that "Recognizes that all individuals are entitled to live in an environment adequate for their health and well-being; and calls upon Member States and intergovernmental and non-governmental organizations... to enhance their efforts towards ensuring a better and healthier environment." ${ }^{3}$

The right to environment was then anchored even at the European regional level in the binding form by the Convention on Access to Information, Public Participation in Decision-Making and Access to Justice in Environmental Matters (1998, the Aarhus Convention), which was adopted by the UN Economic Commission for Europe. ${ }^{14}$

9 DÉJANT-PONS, Marguelonne, PALLEMAERTS, Marc. Human Rights and the Environment. Strasbourg: Council of Europe, 2002. p. 10.

10 BOER, Ben. Human Rights and the Environment: Where Next? In: BOER, Ben (ed.). Environmental Law Dimensions of Human Rights. Oxford: Oxford University Press, 2015. p. 219.

11 BOER, Ben. Human Rights and the Environment: Where Next? In: BOER, Ben (ed.). Environmental Law Dimensions of Human Rights. Oxford: Oxford University Press, 2015. p. 3.

12 See RIVERA - RODRIGUEZ, Luis, E. Is the Human Right to Environment Recognized under International Law? In: Colorado Journal of International Environmental Law and Policy, Vol. 12, No.1, (2001) p. 31-37 or DÉJANT-PONS, Marguelonne, PALLEMAERTS, Marc. Human Rights and the Environment. Strasbourg: Council of Europe, 2002. p. 19.

13 Resolution „Need to Ensure a Healthy Environment for the Well-Being of Individuals", G.A. Res. 45/94, at paras. 1-2, U.N. GAOR, 45th Sess., U.N. Doc. A/RES/45/94 (Dec. 14, 1990).

14 Convention on Access to Information, Public Participation on Decision-making and Access to Justice in Environmental Matters (1998), United Nations, Treaty Series, vol. 
The Aarhus Convention is a new type of convention on international environmental law, which links international environmental law and international human rights law. Right to environment is primarily enshrined in the preamble to the Convention in the wording of "...every person has the right to live in an environment adequate to his or her health and well-being...”. Furthermore, this right is referred to in Article 1 of the Convention, entitled „Purpose“, within the formulation ,in order to contribute to the protection of the right of every person of present and future generations to live in an environment adequate to his or her health and well-being, each Party shall guarantee the rights of access to information, public participation in decision-making, and access to justice in environmental matters in accordance with the provisions of this Convention. "For the first time, substantive human right to environment has been explicitly recognized in the Aarhus Convention in the operative provisions of the international legal instrument at the European level..${ }^{15}$ Article 1 of the Aarhus Convention creates a very specific form of protection of substantive right to environment. In the first part of the article there is evident a clear recognition of the substantive right to environment. However, it is clear from the second part of this article that the protection of this right will be exercised through three procedural rights, which have the unique relationship with the substantive right to environment. ${ }^{16}$

As far as the other regional conventions enshrining the right to environment are concerned, an internationally binding Additional Protocol to the American Convention on Human Rights in the area of Economic, Social, and Cultural Rights (1969), ${ }^{17}$ to the American Convention on Human Rights (1969), ${ }^{18}$ which was adopted within the framework of the Organization of American States, is significant. That additional protocol in Article 11 enshrines the wording „... everyone has the right to live in a healthy environment ... ". As for this protocol the procedure of individual complaints enshrined in the American Declaration of the Rights and Obligations of Man (1948) and the procedure of individual complaints and interstate complaints under the American Convention of Human Rights (1969) can be used. In the case of failure of mentioned extrajudicial remedy the Commission can submit these complaints to the Inter - American Court of Human Rights Court in Costa Rica, San José under the provisions of American Convention of Human Rights (1969).

2161, p. 447.

15 See DÉJANT-PONS, Marguelonne, PALLEMAERTS, Marc. Human Rights and the Environment. Strasbourg: Council of Europe, 2002. p. 16-17.

16 DÉJANT-PONS, Marguelonne, PALLEMAERTS, Marc. Human Rights and the Environment. Strasbourg: Council of Europe, 2002. p. 18.

17 Additional Protocol to the American Convention on Human Rights in the area of Economic, Social, and Cultural Rights (1988), O.A.S. Treaty Series No. 69 (1988) reprinted in Basic Documents Pertaining to Human Rights in the Inter-American System, OEA/Ser. L.V/ II.82 doc.6 rev.1 at 67 (1992).

18 American Convention on Human Rights (1969), O.A.S. Treaty Series No. 36 (1969). 
Alas, even if Article 11 establishes right to environment, this right cannot be invoked under the procedure of individual complaints, given that this protocol only establishes a reporting procedure in relation to the control of application of its content. The Protocol as such enshrines the right to complain about violations of the right to education and the right to freedom of labour only. ${ }^{19}$ This approach is weakening the process of practical application of Article 11. However, the right to environment can be protected indirectly by a wider interpretation of other rights enshrined in the American Convention on Human Rights (1969) using the abovementioned complaint procedures as it is going to be explained later in this paper.

Arab Charter on Human Rights (2004) ${ }^{20}$ include right to environment in its Article 38. This article stipulate that "Everyone shall have the right to an adequate standard of living for himself and his family, ensuring well-being and a decent life, including adequate food, clothing, housing, services and a right to a safe environment. The State Parties shall take appropriate measures within their available resources to ensure the realization of this right.". The Arab Charter on Human Rights create even a controlling mechanism based on reporting procedure under which all state parties of the charter shall submit reports to the Secretary-General of the League of Arab States on the measures they have taken to give effect to the rights and freedoms recognized in this Charter and on the progress made towards the enjoyment thereof. Pursuant to the Charter, there is established, an Arab Human Rights Committee. The Committee shall be composed of seven members elected by secret ballot by the State Parties to the present Charter. The Secretary - General shall transmit these reports to the Committee for its consideration. The Statute of the Arab Court of Human Rights ${ }^{21}$ approved by the Ministerial Council of the LAS on 7 September 2014 create a new Arab Court of Human Rights. However, this statue does not permit individuals or groups, including victims of human rights violations, to file a complaint directly with the Court. Only States parties, and NGOs that are both accredited in a State party and are specifically permitted to do so by that State, can bring cases before the Court. That is why the controlling mechanism of the Arab Charter on Human Rights is considered as a not very effective one.

Human right to environment is enshrined even in the ASEAN Human Rights Declaration (2012). ${ }^{22}$ Point 28 (f) of this Declaration sets out several human

19 ANTON, Donald, K., SHELTON, Dinah. L. Environmental Protection and Human Rights. Cambridge: Cambridge University Press, 2011. p. 519.

20 League of Arab States, Arab Charter on Human Rights, 15 September 1994, available at: https://www.refworld.org/docid/3ae6b38540.html (accessed 11 February 2019)

21 League of Arab States, Arab Charter on Human Rights, 15 September 1994, available at: https://www.refworld.org/docid/3ae6b38540.html (accessed 11 February 2019)

22 Association of Southeast Asian Nations (ASEAN), ASEAN Human Rights Declaration, 18 November 2012, available at: https://www.refworld.org/docid/50c9fea82.html [accessed 21 January 2019] 
environmental rights, including human right to the environment. According to the diction of this provision "Every person has the right to an adequate standard of living for himself or herself and his or her family including... The right to a safe, clean and sustainable environment...”.

Promotion of this declaration is ensured by its point 38 under which ASEAN Member States share a common interest in and commitment to the promotion and protection of human rights and fundamental freedoms which shall be achieved through, inter alia, cooperation with one another as well as with relevant national, regional and international institutions/organisations, in accordance with the ASEAN Charter. In order to promote the application of the ASEAN Human Rights Declaration can be used even the ASEAN Intergovernmental Commission on Human Rights (AICHR) inaugurated by the ASEAN Leaders on 23 October 2009 at the 15th ASEAN Summit in Cha-Am Hua Hin, Thailand. The AICHR members are called Representatives, who are nominated by their respective Governments. The AICHR holds two regular meetings per year and additional meetings when necessary, and reports to the ASEAN Foreign Ministers. However, this implementing mechanism is not that strong comparing to the other mentioned regional human rights mechanisms. The practice of the Commission remains, at this point, at level of advice, encouragement, consultation, training workshops, and the development of common approaches on the promotion and protection of human rights in the region. ${ }^{23}$

The Special Dimension of the Protection of the Rights of the Environment is developed by the African Charter on Human and Peoples' Rights (1981, hereinafter referred to as the African Charter), ${ }^{24}$ adopted within the framework of the African Unity Organization, later transformed into the African Union. African Charter states in Article 24, „All peoples shall have the right to a general satisfactory environment favourable to their development. “. In the case of this Convention, however, it is rather a collective right belonging to all nations, although its individual dimension is not excluded. The African Charter allows for the filing of a complaint on this right to the African Commission on Human and Peoples' Rights, ${ }^{25}$ as a quasi-judicial body with a non-binding investigative and conciliation power, which may in certain circumstances also refer the case to the African Court on Human and Peoples' Rights. ${ }^{26}$ This court can decide on referred cases in a binding manner.

23 See BOER, Ben. Environmental Law and Human Rights in the Asia-Pacific. In: BOER, Ben (ed.) Environmental Law Dimensions of Human Rights. Oxford: Oxford University Press, 2015. p. 149.

24 African Charter on Human and Peoples' Rights (1981), OAU Doc. CAB/LEG/67/3 rev. 5, 21 I.L.M. 58 (1982).

25 As for the activity of this body look JANKUV, Juraj, LANTAJOVÁ, Dagmar, BLAŠKOVIČ, Kristián, BUCHTA, Tomáš, ARBET, Daniel. Medzinárodné právo verejné. Druhá čast. Plzeň: Aleš Čeněk, 2016. p. 214-215.

26 As for the activity of this body look JANKUV, Juraj, LANTAJOVÁ, Dagmar, BLAŠKOVIČ, 
From the practice of the African Commission on Human and Peoples' Rights, the case concerning the protection of the right to environment, abbreviated as Ogoni v. Nigeria (2001), ${ }^{27}$ is already known. In the context of this case, in March 1996, two non-governmental organizations filed a complaint. It was the Social and Economic Rights Action Centre (Nigeria) and the Centre for Economic and Social Rights (USA). This complaint dealt with a relatively large number of alleged serious violations of the human rights of the indigenous people of Ogoni, understood as an ethnic minority in the Nigerian state of Rivers. The complaint alleged that the military government of Nigeria was directly involved in irresponsible oil mining practices in the Ogoni region.

The Complainants allege that the Nigerian Government violated e.g. the right to clean environment as recognised under Article 24 of the African Charter by failing to fulfil the minimum duties required by this right. This, the Complainants allege, the government has done by directly participating in the contamination of air, water and soil and thereby harming the health of the Ogoni population, by failing to protect the Ogoni population from the harm caused by the NNPC Shell Consortium but instead using its security forces to facilitate the damage and by failing to provide or permit studies of potential or actual environmental and health risks caused by the oil operations.

African Commission on Human and Peoples' Rights found that the Federal Republic of Nigeria violated e.g. Article 24 of the African Charter in this case. This Commission appealed to the government of the Federal Republic of Nigeria to ensure protection of the environment, health and livelihood of the people of Ogoni, by stopping all attacks on Ogoni communities and leaders by the Rivers State Internal Securities Task Force and permitting citizens and independent investigators free access to the territory, by conducting an investigation into the human rights violations described above and prosecuting officials of the security forces, NNPC and relevant agencies involved in human rights violations, by ensuring adequate compensation to victims of the human rights violations, including relief and resettlement assistance to victims of government sponsored raids, and undertaking a comprehensive clean-up of lands and rivers damaged by oil operations, by ensuring that appropriate environmental and social impact assessments are prepared for any future oil development and that the safe operation of any further oil development is guaranteed through effective and independent oversight bodies for the petroleum industry and by providing information on health and environmental risks and meaningful access to regulatory and decision-making bodies to communities likely to be affected by oil operations.

Kristián, BUCHTA, Tomáš, ARBET, Daniel. Medzinárodné právo verejné. Druhá čast'. Plzeň: Aleš Čeněk, 2016. p. 215.

27 African Commission on Human and Peoples' Rights, 155/96: Social and Economic Rights Action Centre (SERAC) and Centre for Economic and Social Rights (CESR) v. Nigeria, 27 October 2001, 30th Ordinary Session, 13-27 October 2001. Banjul, Gambia. 
This decision, for the first time in history, ruled directly that certain state violated substantive right to environment and ordered extensive environmental clean-up measures to be taken by this state. ${ }^{28}$ The African Charter is thus the only regional mechanism that allows direct access to environmental protection from the quasi-judicial authorities, but also from the international court.

From the contents of the abovementioned legal arrangements it can be stated that the enactment of the substantive right to environment is visible in international public law. Given the enshrining of this right in the Stockholm Declaration, the Aarhus Convention, within the American, African and Pacific regions, and the enshrinig of this right in non-binding and soft law documents, it is clear, that more detailed mechanisms for protection of this right are being developed in practice. This process is also supported by the practice of many states that incorporate this right into their legal orders and create scope for the customary enactment of this right. ${ }^{29}$

We therefore take the view that the individually perceived substantive human right to the environment is now widely recognized ${ }^{30}$ and may, in a relatively short time, be embedded in the customary form binding erga omnes. There are even opposite views in the science of international public law presented consistently e.g. by professor Handl considering the concept of substantive human right to the environment highly questionable because of various reasons. ${ }^{31}$ Arguments of this author are relative clearly and precisely denied by professor RodriguezRivera, by our opinion, ${ }^{32}$ and we are leaning towards his point of view.

The views of professor Rodriguez-Rivera and other international public law scientist are strongly supported by recent report Framework Principles on Human Rights and the Environment (2018) ${ }^{33}$ of professor Knox - Special Rap-

28 See BOER, Ben. Human Rights and the Environment: Where Next? In: BOER, Ben (ed.). Environmental Law Dimensions of Human Rights. Oxford: Oxford University Press, 2015. p. 224.

29 CULLET, Philippe. Human Rights and Climate Change. Broadening the Right to Environment. In: CARLANE, Cinnamon, P., GRAY, Kevin, R., TARASOFSKY, Richard, G. (eds.). The Oxford Handbook of International Climate Change Law. Oxford: Oxford University Press, 2016. s. 507.

30 ZÁSTĚROVÁ, Jana. Jednotlivci: právo na životní prostředí. In: ŠTURMA, Pavel. a kol. Mezinárodní právo životního prostředí, I. část (obecná). Beroun: Eva Rozkotová-IFEC, 2004. s. 37.

31 ANTON, Donald, K. - SHELTON, Dinah, L. Environmental Protection and Human Rights. Cambridge: Cambridge University Press, 2011. s.139-141 and HANDL, Günther. Human Rights and Protection of the Environment. In: EIDE, Asbjørn, KRAUSE, Catarina, ROSAS, Allan (eds.). Economic, Social and Cultural Rights. Nijhoff, 2001. p. 303-315.

32 RIVERA - RODRIGUEZ, Luis, E. Is the Human Right to Environment Recognized under International Law? In: Colorado Journal of International Environmental Law and Policy, Vol. 12, No.1, (2001) p. 31-37.

33 KNOX, John. Framework Principles on Human Rights and the Environment, UN Doc. A/ HRC/37/59(2018). 24 p. 
porteur on human rights and the environment of the United Nations Human Rights Council.

Under this report "Human rights and environmental protection are interdependent. A safe, clean, healthy and sustainable environment is necessary for the full enjoyment of human rights, including the rights to life, to the highest attainable standard of physical and mental health, to an adequate standard of living, to adequate food, to safe drinking water and sanitation, to housing, to participation in cultural life and to development, as well as the right to a healthy environment itself, which is recognized in regional agreements and most national constitutions. At the same time, the exercise of human rights, including rights to freedom of expression and association, to education and information, and to participation and effective remedies, is vital to the protection of the environment." ${ }^{34}$

Further prof. Knox emphasizes that "The obligations of States to respect human rights, to protect the enjoyment of human rights from harmful interference, and to fulfil human rights by working towards their full realization all apply in the environmental context. States should therefore refrain from violating human rights through causing or allowing environmental harm; protect against harmful environmental interference from other sources, including business enterprises, other private actors and natural causes; and take effective steps to ensure the conservation and sustainable use of the ecosystems and biological diversity on which the full enjoyment of human rights depends. While it may not always be possible to prevent all environmental harm that interferes with the full enjoyment of human rights, States should undertake due diligence to prevent such harm and reduce it to the extent possible and provide for remedies for any remaining harm.". ${ }^{35}$

A very important moment as for the protection of substantive right to environment is to identify the legal boundaries and the obstacles to the enforcement of this public subjective right in practice and to create relevant legal regulations. In this context, it is very useful to reflect on its content. In its most basic form, right to environment could be associated with the existence of an environment that is suitable for sustaining a human life that is a "viable“ environment in a literal sense. From the point of view of the content of substantive human right to environment, it is also interesting to look at the definition of the term „environment". In our view, it is appropriate to draw attention to the definition of the environment in the Convention on Civil Liability for Environmental Damage (1993) ${ }^{36}$ which defines the environment as „natural and non-living natural resources such as air, water, soil, fauna and flora, and interactions between these

34 KNOX, John. Framework Principles on Human Rights and the Environment, UN Doc. A/ HRC/37/59(2018). p. 6.

35 KNOX, John. Framework Principles on Human Rights and the Environment, UN Doc. A/ HRC/37/59(2018). p. 6.

36 Convention on Civil Liability for Damage resulting from Activities Dangerous to the Environment, ETS No.150, Lugano, 21/06/1993. 
factors, as well as the objects that form part of the cultural heritage and the characteristics of the earth's surface. , In the context of full securing of right to environment, in connection with this definition, it is necessary to ensure that natural and non-living resources such as air, water, soil, fauna and flora are of such a quality as to enable the full and healthy life of the individual or community of the people. In the context of the interpretation of the content of right to environment, it must be borne in mind that the objective of international environmental law is to achieve sustainable development. From this point of view, the right to environment can also be defined as the right of the person to live in the environment, which allows him to satisfy his or her basic living needs and to use it in his favour, so as not to reduce the diversity of nature and preserve the natural functions of ecosystems. The right of an individual to environment as a right which has the character of a subjective public right and enabling to meet the human being basic living needs, must also be ensured through the obligations of the States. The international legal arrangement in the area should reflect even the fact that the state not only guarantees, but also provides realistically (with the use of legal and economic instruments) the state where its territory or the environment is not burdened by human activity beyond the limit values for permissible levels of environmental pollution laid down in a standard of international public law and related national generally binding legislation or laid down by a decision of the competent national authority. States should take even measures to prevent the risk of irreversible or serious damage to the environment. In order to ensure the protection of right to environment, it is also necessary to resolve its relation to the right to water and the right to sanitation. Both rights are, in our opinion, part of right to environment in the scope of its wider interpretation. It is also necessary to address the question of the nature of the right to environment, since in its international arrangements in the area contains both its individual and collective understanding.

\section{Indirect protection of the substantive human right to environment under international public law}

Substantive human right to the environment can be protected, in the spirit of some rules of public international law, indirectly as well. The means of such indirect protection include, protection through procedural environmental rights included into some of the rules international environmental law, protection via extended interpretation of the scope of certain human rights anchored in the rules of international human rights law, protection by practical application of the other substantive environmental rights enshrined in international human rights law and protection by the rules of international environmental law itself. 
3.1 Indirect protection of substantive human right to the environment by procedural environmental rights

Indirect protection of substantive human right to the environment by procedural environmental rights included into some of the rules international environmental law is a relatively new tool of international community. Procedural environmental rights have become a solid part of many non-binding documents and binding international law conventions in the past decades, particularly in the area of international environmental law. Comprehensive analysis of their enactment in international environmental law goes beyond the scope of this article, and we will therefore only mention some of the key documents and conventions that are fundamental to the formulation and enshrinement of these rights. ${ }^{37}$ Procedural environmental rights appear first in a non-binding international document, namely the World Nature Charter (1982), ${ }^{38}$ adopted as UN General Assembly Declaration n. 37/7 (1982), which enshrined the right to participate in decision-making process in the environmental matters, as well as the right to access to justice in environmental matters in point 23 of this document as it follows: "All persons, in accordance with their national legislation, shall have the opportunity to participate, individually or with others, in the formulation of decisions of direct concern to their environment, and shall have access to means of redress when their environment has suffered damage or degradation. According to this point, all persons will, in accordance with their national legislation, be given the opportunity to participate individually or with others in the formulation of decisions directly related to their environment and to have access to remedies in the event of damage to or degradation of their environment."

The first binding international treaty which included procedural environmental rights is probably the Convention on Environmental Impact Assessment in a Transboundary Context $(1991)^{39}$ adopted by the United Nations Economic Commission for Europe. This Convention established one of the dimensions of the right to public participation in decision-making in environmental matters namely the right of the public to participate in relevant environmental impact assessment procedures regarding proposed activities in Article 2 (6) and the right to environmental information in the Article 3 (8). The precise incorporation of all three procedural environmental rights is contained in the Principle 10 of the Declaration of Environment and Development $(1992)^{40}$ from Rio de Janeiro.

37 For comprehensive survey of international conventions which include procedural environmental rights see KiSS, Alexandre. Le droit á lenvironment en tant que moyen d'assurer la mise en oeuvre de traités internationaux. In: Šturma, Pavel. et al. Implementation and Enforcement of International Environmental Law. Praha: Univerzita Karlova, 2002. pp. $38-45$.

38 World Charter for Nature, UN Doc. A/Res./37/7(1982).

39 Convention on Environmental Impact Assessment in a Transboundary Context (1991), United Nations, Treaty Series, vol. 1989, p. 309.

40 Rio Declaration on Environment and Development (1992), UN Doc. A/CONF.151/26 (vol. I) 
The Declaration establishes the commitment of States to ensure at every national level the right to information on the environment, the right to participate in environmental decision-making and the right to access to legal and administrative proceedings in environmental matters as it follows: "At the national level, each individual shall have appropriate access to information concerning the environment that is held by public authorities, including information on hazardous materials and activities in their communities, and the opportunity to participate in decision-making processes. States shall facilitate and encourage public awareness and participation by making information widely available. Effective access to judicial and administrative proceedings, including redress and remedy, shall be provided.".

The link between the issue of protection of substantive human right to the environment and procedural environmental rights was then outlined by the abovementioned regional Convention on Access to Information, Public Participation in Decision-Making and Access to Justice in Environmental Matters (1998, the Aarhus Convention). The Aarhus Convention, in its Article 1, states as follows: "In order to contribute to the protection of the right of every person of present and future generations to live in an environment adequate to his or her health and well-being, each Party shall guarantee the rights of access to information, public participation in decision-making, and access to justice in environmental matters in accordance with the provisions of this Convention.".

As it was mentioned above, this provision, on the one hand, contains the declaratory recognition of the existence of substantive right to environment. This provision stipulates, on the other hand, also the main goal of the Aarhus Convention to protect substantive right to environment through three procedural environmental rights - right of access to environmental information, right to participate in environmental decision-making and right of access to legal protection in environmental matters, in accordance with the provisions of the Convention, and acts of national authorities in the field of application of their national rules. The Aarhus Convention provides, in its content, the necessary definitions, general provisions, detailed legal regulations for all three procedural environmental rights, and creates scope for the gradual completion of the Convention's control mechanisms, including mechanisms of communications from the public to the international authority in case of violation of these rights.

The control mechanisms of the Convention shall be established in the spirit of Articles 10 (2), 12, 14 and 15. Article 10 (2) in the first sentence states „... At their meetings, the Parties shall keep under continuous review the implementation of this Convention on the basis of regular reporting by the Parties ...". This is a reporting procedure similar to the reporting procedures of the UN human rights conventions. Article 12 creates a special body of the Aarhus Convention - Secretariat. Article 10 (1) creates another specific international body of the Aarhus Convention - Meeting of the parties. Article 15 further states that „... 
The Meeting of the Parties shall establish, on a consensus basis, optional arrangements of a non-confrontational, non-judicial and consultative nature for reviewing compliance with the provisions of this Convention. These arrangements shall allow for appropriate public involvement and may include the option of considering communications from members of the public on matters related to this Convention...." These authorities have been created over time. Several bodies have been set up within the meetings of the parties. From the point of view of compliance with the provisions of the Convention, it is probably the most important the Compliance Committee, also called the Aarhus Committee, created by the Decision 1/7 (2002) on the examination of the compliance of the Meeting of the parties. The mechanism of this committee may be triggered by the communication of a Contracting Party on compliance by another Contracting Party with the Convention, by the communication by a Party of compliance with the Convention on its part, by the reference of the Secretariat of the Meeting of the Parties to the Aarhus Committee, and by communication of compliance by the State to the Convention made by members of the public (individuals or legal personalities). In addition, the Compliance Committee may examine compliance with the Convention on its own initiative, make recommendations, prepare compliance reports at the request of a meeting of the Parties, and monitor, assess and facilitate the implementation of the reporting requirements of the States pursuant to Article 10 (2). Details regarding the implementation of the reporting procedure were elaborated in the framework of Decision No. 1/8 (2002) on the Reporting Requirements of the Meeting. In addition to the Aarhus Committee, the Secretariat has an important role to play in this procedure.

Given the recent creation of the Aarhus Committee, there is not enough information in the literature to make it absolutely clear the nature of this body. But there is the potential for creating a quasi-judicial mechanism. ${ }^{41}$

The Aarhus Committee currently records a smaller number of communications from states against another state and a higher number of communications from the public (individuals) against the state. In several cases (including the Slovak Republic), the Aarhus Committee found non-compliance with the provisions of the Aarhus Convention. ${ }^{42}$

41 See SHAW, Malcolm, N. International Law. Sixth Edition. Cambridge: Cambridge University Press, 2008. pp. 848-849 and website www.unece.org/env/pp/compliance.htm.

42 See JANKUV, Juraj. Ludské právo na životné prostredie a mechanizmy jeho ochrany v medzinárodnom práve. In: Acta Universitatis Carolinae - Iuridica, Praha, No. 4, 2006 (issued in 2008), pp. 75-76 and website http://www.unece.org/env/pp/pubcom.htm. 
3.2 Indirect protection of substantive human right to environment through the provision of universal and regional conventions on the protection of human rights of international human rights law

Indirect protection of substantive human right to environment through the provision of universal and regional conventions on the protection of human rights of international human rights law is another frequently used way of protecting this right. Within the framework of the United Nations human rights mechanisms, right to environment can be protected indirectly through the provisions of the International Covenant on Civil and Political Rights (1966). ${ }^{43}$ From the point of view of control mechanisms, indirect protection of human right to environment is possible within the framework of the procedure of communications from individuals under the Optional Protocol to the International Covenant on Civil and Political Rights (1966). In line with the jurisprudence of the Human Rights Committee, it is possible, for example, by extended explanation of the Article 6 (1), which stipulates the right to life, following the case of E.H.P. v. Canada (No. 67/1980). ${ }^{44}$ Another dimension of the protection of human right to environment is the extended explanation of the Article 27, which lays down the rights of persons belonging to ethnic, religious or linguistic minorities. Following the case Lake Lubicon Band v. Canada (No 167/1984) ${ }^{45}$ could be the right to environment indirectly protected by the application of the right of persons belonging to ethnic, religious or linguistic minorities to enjoy their own culture.

Within the framework human rights mechanisms of the Council of Europe, the right to environment can be indirectly protected through the provisions of the European Convention for the Protection of Human Rights and Fundamental Freedoms (1950). ${ }^{46}$ A more detailed overview of individual human rights enshrined in the European Convention for the Protection of Human Rights and Fundamental Freedoms of 1950 as well as the mechanism for their protection within the European Court of Human Rights has already been commented on in the science of international public law in a profound manner ${ }^{47}$ so it is not necessary to comment it in details.

43 International Covenant on Civil and Political Rights (1966). United Nations, Treaty Series, vol. 999, p. 171.

44 UN Human Rights Committee, Communication No. 67/1980 E.H.P. v Canada (1990), CCPR/17/D/67/1980.

45 UN Human Rights Committee, Communication No. 167/1984, Lubicon Lake Band v Canada, UN Doc. A/45/40, Vol. II., p. 23-24.

46 European Convention for the Protection of Human Rights and Fundamental Freedoms, as amended by Protocols Nos. 11 and 14, 4 November 1950, ETS 5.

47 See HARRIS, David, O’Boyle, Michael, BATES, Ed, BUCKLEY, Carla. Harris, O'Boyle, and Warbrick: Law of the European Convention on Human Rights. Fourth Edition. Oxford: Oxford University Press, 2018. 1056 p., ŠTURMA, Pavel. Mezinárodní a evropské kontrolní mechanismy v oblasti lidských práv. 3.doplněné vydání. Praha: C. H. Beck, 2010. p. 32-39 or JANKUV, Juraj. Mechanizmy ochrany ludských environmentálnych práv $v$ medzinárodnom práve verejnom, $v$ práve európskej únie a v právnom poriadku Slovenskej republiky. Praha: 
For the purpose of protecting substantive human right to environment, it is possible to use a procedure of individual complaints in proceedings before the European Court of Human Rights. The European Court of Human Rights, in the case of Kyrtatos v. Greece (No 41666/98), ${ }^{48}$ stated that there was no right to environment enshrined in the European Convention but indicated the possibility of linking protection of environment with Article 8 of the European Convention, which establishes the right to respect for private and family life, housing and correspondence. This has already been confirmed by the earlier case law of the European Court of Human Rights. A key case in this respect is the case López Ostra v. Spain (No 16798/90). ${ }^{49}$

Indirect protection of substantive human right to environment is possible even through the provisions of the American Declaration of Human Rights and Responsibilities (1948) ${ }^{50}$ and the American Convention on Human Rights $(1969)^{51}$ as it was mentioned above already. The American Declaration of the Rights and Obligations of Man (1948) and the American Convention on Human Rights (1969) create a system of human rights protection, similar to the European Convention of Human Rights and Fundamental Freedoms (1950) of the Council of Europe.

Both the Declaration and the Convention enshrine a comprehensive catalogue of human rights and the monitoring mechanisms for monitoring of respecting enshrined human rights in the scope of activity of the Inter-American Commission on Human Rights and the Inter-American Court of Human Rights. The Inter-American Commission on Human Rights was established in 1959 and is based in Washington. It has its own monitoring mechanisms for the protection of human rights in the form of a wide range of rapporteurs, for the rights of indigenous peoples, women, children, and so on. It also investigates individual complaints and inter-state complaints about human rights violations and proposes an extra judicial settlement. These complaints are investigated in the context of the individual complaint procedure enshrined in the American Declaration of the Rights and Obligations of Man (1948) and the procedure of individual complaints and inter-state complaints under the American Convention of Human Rights (1969). In the case of failure of mentioned extrajudicial remedy the Commission can submit these complaints to the Inter - American Court of Human Rights Court in Costa Rica, San José under the provisions of American Convention of Human Rights (1969). The Inter-American Human Rights Court

Leges. 2018. p. 29-34.

48 Kyrtatos v. Greece, Judgement, Merits and just satisfaction, App. No. 41666/98, 22nd May 2003, European Court of Human Rights.

49 López Ostra v. Spain, Judgement, Merits and just satisfaction, App. No 16798/90, 9th December 1994, European Court of Human Rights.

50 American Declaration of the Rights and Duties of Man (1948), OEA/Ser. L./V.II.23, doc. 21, rev. 6 (1948).

51 American Convention on Human Rights (1969). OAS Treaty Series No. 36. 1144 UNTS 123. 
is gradually developing its case law, following the established human rights enshrined in the American Convention of Human Rights (1969), both in the context of the individual complaint's procedure and the inter-state complaints procedure. His jurisprudence extends creatively the interpretation of individual provisions and gradually protects the rights not mentioned in the Convention, including the right to environment. A detailed analysis of the case-law of those bodies on indirect environmental protection already exceeds this contribution, but at least reference to individual case-law can be mentioned.

In the context of the indirect protection of substantive human right to environment, the Yanomami v. Brazil Case (1985) ${ }^{52}$ was dealt with by the Inter-American Commission on Human Rights as the first one. In the context of the indirect protection of substantive human right to environment, the breakthrough case was the Awas Tigni v. Nicaragua Case $(2001)^{53}$ dealt with by the Inter-American Court for Human Rights after a prior submission by the Inter-American Commission on Human Rights. An important case of the practice of both institutions is the Sarayaku v. Ecuador Case (2012) $)^{54}$ as well as the case of Saramaka v. Suriname Case (2007). ${ }^{55}$ All the cases mentioned were lodged by representatives of the communities of indigenous peoples or similar communities. All the four groups of complainants succeeded in protecting the environment, which was severely damaged by government licenses for its industrial use. Inter-American Court for Human Rights extensively explained different rights enshrined in the American Convention of Human Rights (1969) e.g. the the Article 21 (right to property), Article 25 (right to fair trial), Article 4 (1) (right to life) etc. in order to protect the right to environment of the complainants.

3.3 Indirect protection of substantive human right to the environment by practical application of the other material environmental rights enshrined in international human rights law

Protection of substantive right to the environment under international law is closely related to the international protection of two other substantive environmental rights - right to water rand the right to sanitation. The right to sanitation is also used by the science of international law in the form of the right to safe hygienic conditions of environment. ${ }^{56}$ Both of those forms of titles of rights have the same contents.

52 Case of Yanomami v. Brazil, Case No. 7615, Resolution No. 12/85 of March 5, 1985, InterAmerican Commission of Human Rights.

53 Case of the Mayagna (Sumo) Awas Tigni Community v. Nicaragua, Judgement of August 31, 2001, Inter-American Court of Human Rights, Ser.C, No.79 (2001).

54 Case of the Kichwa Indigenous People of Sarayaku v. Ecuador. Judgment of June 27, 2012. Inter-American Court of Human Rights, Series C, No. 245.

55 Case of the Saramaka People v. Suriname, Preliminary Objections, Merits, Reparations, and Costs, Judgment of November 28, 2007, Inter-American Court of Human Rights.

56 See MASLEN, Michal. Právna úprava starostlivosti o vody v Slovenskej republike. Praha: 
Anchoring of human right to water as well as the right to sanitation (right to safe hygienic conditions of environment) in international public law occurred primarily through some of international treaties falling within the framework of international human rights law. Among the international treaties which explicitly enshrine both rights are the Convention on the Elimination of All Forms of Discrimination against Women (1979, Article 14 (2)), the Convention on the Rights of the Child (1989, Article 24) and the Convention on the Rights of Persons with Disabilities (2006, Article 28). ${ }^{57}$

Article 14(2) of the Convention on the Elimination of All Forms of Discrimination against Women (1979) reads: „States Parties shall take all appropriate measures to eliminate discrimination against women in rural areas in order to ensure, on a basis of equality of men and women, that they participate in and benefit from rural development and, in particular shall ensure to such women the right:... (h) to enjoy adequate living conditions, particularly in relation to housing, sanitation, electricity and water supply, transport and communications.".

Article 24 of the Convention on the Rights of the Child (1989) reads as follows: "(1) States Parties recognize the right of the child to the enjoyment of the highest attainable standard of health and to facilities for the treatment of illness and rehabilitation of health. States Parties shall strive to ensure that no child is deprived of his or her right of access to such health care services. (2) States Parties shall pursue full implementation of this right and, in particular, shall take appropriate measures: ... (c) To combat disease and malnutrition, ... through the provision of adequate nutritious foods and clean drinking water, taking into consideration the dangers and risks of environmental pollution; ... (e) To ensure that all segments of society, in particular parents and children, are informed, have access to education and are supported in the use of basic knowledge of child health and nutrition, the advantages of breastfeeding, hygiene and environmental sanitation and the prevention of accidents; ...”.

Article 28 of the Convention on the Rights of Persons with Disabilities (2006) states: "1. States Parties recognize the right of persons with disabilities to an adequate standard of living for themselves and their families, including adequate food, clothing and housing, and to the continuous improvement of living conditions, and shall take appropriate steps to safeguard and promote the realization of this right without discrimination on the basis of disability. 2. States Parties recognize the right of persons with disabilities to social protection and to the enjoyment of that right without discrimination on the basis of disability, and shall take appropriate steps to safeguard and promote the realization of this right, including measures: (a) To ensure equal access by persons with disabilities to clean water services, and to

Leges, 2017. s. 10-11.

57 See MASLEN, Michal. Právna úprava starostlivosti o vody v Slovenskej republike. Praha: Leges, 2017. s. 10-12. 
ensure access to appropriate and affordable services, devices and other assistance for disability-related needs; ...”.

A key document to recognize both rights at the level of international public law is the Resolution No. 64/292 of the General Assembly of the United Nations of 28 July 2010. ${ }^{58}$ In this resolution are both of mentioned rights considered as one substantive right in its point 1 as follows: „The General Assembly...Recognizes the right to safe and clean drinking water and sanitation as a human right that is essential for the full enjoyment of life and all human rights". The existence of both rights in the form of one substantive right is confirmed by the subsequent Adoption of the Report of the Special Rapporteur on the human right to safe drinking water and sanitation Catarina de Albuquerque at 4 July 2011, ${ }^{59}$ discussed at the 18th session of the United Nations Human Rights Council and Resolution No. 24/18 "The human right to safe drinking water and sanitation. " 60 of the UN Human Rights Council itself.

Both rights are close. They could be considered as a part of one substantive right but even as two independent substantive rights. Under the views of science of international public law the human right to water and the human right to sanitation are two distinct but related human rights. ${ }^{61}$ This view is also supported by fact that those rights can be indirectly protected separately through the case-law of the European Court of Human Rights, following individual complaints by individuals against breaches of certain rights under the European Convention for the Protection of Human Rights and Fundamental Freedoms (1950 ECHR). The human right to water can be protected indirectly in the context of Article 8 of the ECHR enshrining the right to respect for private and family life. This approach demonstrates, for example, the case of Dubetska and others against Ukraine (2011). ${ }^{62}$ The human right to sanitation can be protected in the context of Article 5 of the ECHR establishing the right to liberty as well as Article 3 of the ECHR providing for right to prohibition of torture and inhuman or degrading treatment. This approach is clear, for example, in the case of Riad and Idiab against Belgium (2008). ${ }^{63}$

58 Resolution adopted by the General Assembly on 28 July 2010, No. 64/292. "The human right to water and sanitation". UN Doc. A/RES/64/292 (2010)

59 Report of the Special Rapporteur on the human right to safe drinking water and sanitation, Catarina de Albuquerque. UN Doc. A/HRC/18/33, 4 July 2011.

60 Resolution adopted by the Human Rights Council 24/18. The human right to safe drinking water and sanitation. UN Doc. A/HRC/RES/24/18. 27 September 2013.

61 COLLECTIVE OF AUTHORS. WaterLex. The Human Rights to Water and Sanitation. An Annotated Selection of International and Regional Law and Mechanisms. Geneva: WaterLex. 2017. p. 6

62 Dubetska and Others v Ukraine, Judgment, Merits and Just Satisfaction, App. No. 30499/03, 10. February 2011, European Court of Human Rights.

63 Riad and Idiab v Belgium, Judgment, Merits and Just Satisfaction, Applications No. 29787/03 and No. 29810/03, 24 January 2008. European Court of Human Rights. 
The right to water and right to sanitation is anchored in many other international documents. The profound analyse of those documents goes beyond the scope of this article. ${ }^{64}$

That is why we will close this part of article by stating that formulation and protection of both mentioned substantive environmental rights clearly contribute to the protection of substantive right to environment, given the fact that it contributes to the protection of certain environmental dimensions protected by right to environment.

3.4 Indirect protection of substantive human right to environment by the rules of international environmental law itself

Substantive human right to environment is indirectly protected by the rules of international environmental law itself. Creation of this branch of international public law was required by severe deterioration of environment of the planet Earth due to unregulated human activity. The most serious environmental problems are currently the damage to the Earth's ozone layer, atmospheric pollution by exhalates and the associated greenhouse effect, pollution of rivers, seas and oceans by sewage, discharges of hazardous waste into seas, pollution and tectonic disasters as a result of nuclear experiments and accidents, chemical accidents, deforestation as well as associated desertification and irresponsible genetic manipulation. As a result of these factors, the balance of the ecosystem of the Earth is disturbed, what causes its abnormal functioning. ${ }^{65}$

International environmental law can be defined as a set of principles, institutes and rules of international law governing the protection of the environment at global and regional level as well as in the area of outer space. The development of this branch or sub-branch of international public law was accelerated mainly by adoption of the already mentioned Declaration of the United Nations Conference on the Human Environment adopted at the United Nations Conference on the Human Environment, June 5-16, 1972, Stockholm and the Rio Declaration on Environment and Development ${ }^{66}$ adopted at the United Nations Conference on Environment and Development, June 3-14, 1992, Rio de Janeiro. Standards of international environmental law, developed under principles of abovementioned declarations, are designed to help to protect the biosphere from significant deterioration, prevent its imbalance and, in the current circumstances, primarily to ensure sustainable development of the environment. International environmental law is the law of international cooperation. This cooperation takes

64 For detailed commentary to relevant international documents see COLLECTIVE OF AUTHORS. WaterLex. The Human Rights to Water and Sanitation: An Annotated Selection of International and Regional Law and Mechanisms. Geneva: WaterLex. 2017. 212 p.

65 JANKUV, Juraj, LANTAJOVÁ, Dagmar, BLAŠKOVIČ, Kristián, BUCHTA, Tomáš, ARBET, Daniel. Medzinárodné právo verejné. Druhá čast'. Plzeň: Aleš Čeněk, 2016. s.94.

66 Rio Declaration on Environment and Development (1992). UN Doc. A/CONF.151/26 (vol. I); 31 ILM 874 (1992) 
place directly between States, with the participation of universal and regional international organizations as well as within these organizations. Standards in the field of international environmental law are contained in some rules of general customary international law, in three hundred universal, regional and subregional treaties, in more than a thousand bilateral treaties, and in dozens of UN resolutions and other documents and other universal and regional international organizations. ${ }^{67}$ Comprehensive analysis of these sources of international environmental law goes beyond the scope of this article. The science of international public law analysed these sources in a profound manner already. ${ }^{68}$

That is why, we only state in this place that international environmental law itself is clearly contributing to the protection of substantive human right to environment, given that it contributes to the protection of all environmental values protected in the scope of right to environment. International environmental law is the youngest branch of international public law.

\section{Conclusion}

Scientific discussion on the stabilization of the new human right to environment, understood as substantive right, strengthened in the mid-sixties of the twentieth century. The result of this discussion was the embodying of this right, according to some views of international public law science understood as a basic human right into an international document of a fundamental nature for the protection of the environment - Declaration of the United Nations Conference on the Human Environment adopted at the United Nations Conference on the Human Environment, June 5-16, 1972, Stockholm. Declaration of the United Nations Conference on the Human Environment. Principle 1 of this declaration reads: "Man has the fundamental right to freedom, equality and adequate conditions of life, in an environment of a quality that permits a life of dignity and well-being, and he bears a solemn responsibility to protect and improve the environment for present and future generations..

The enactment of human right to environment in the Declaration of the Stockholm Conference on the Human Environment has influenced next inter-

67 See POTOČNÝ, Miroslav, ONDǨEJ, Jan. Mezinárodní právo veřejné. Zvláštní část. 6. doplněné a přepracované vydání. Praha: C. H. Beck 2011. p. 180.

68 See for example BIRNIE, Patricia, BOYLE, Alan, REDGWELL, Catherine. International Law and the Environment. Third Edition. New York: Oxford University Press 2009. 888 p, SANDS, Philippe, PEEL, Jacqueline, FABRA, Adriana, MACKENZIE, Ruth. Principles of International Environmental Law. Third Edition. Cambridge: Cambridge University Press, 2012. 926 p. or LOUKA, Eli. International Environmental Law. Fairness, Effectiveness, and World Order. Cambridge: Cambridge University Press, 2006. 518 p., ŠTURMA, Pavel et al. Mezinárodní právo životního prostředí, I. část (obecná). Beroun: Eva Rozkotová-IFEC, 2004. 193 p. ISBN 80-903409-2-X and DAMOHORSKÝ, Milan et al. Mezinárodní právo životního prostředí, II. část (zvláštní). Beroun: Eva Rozkotová-IFEC, 2008. 318 p. ISBN 97880-903409-8-9. 
national public law normativity. This right was implemented in various other international instruments and conventions adopted within the framework of the United Nations, conferences organized by the United Nations, international organizations associated to the United Nations as well as conventions and documents international regional organizations.

Leading document enshrining right to environment at the European regional level is Convention on Access to Information, Public Participation in DecisionMaking and Access to Justice in Environmental Matters (1998, the Aarhus Convention). Aarhus convention contains the declaratory recognition of the existence of substantive right to environment. But in fact, does not protect this right directly since protects this right through three procedural environmental rights.

Therefore, the leading mechanism as far as the direct protection of this right is concerned in general is the African Charter on Human and Peoples' Rights (1981, hereinafter referred to as the African Charter), adopted within the framework of the African Unity Organization, later transformed into the African Union. African Charter states in Article 24, „All peoples shall have the right to a general satisfactory environment favourable to their development.". In the case of this Convention, however, it is rather a collective right belonging to all nations, although its individual dimension is not excluded. The African Charter allows for the filing of a complaint on this right to the African Commission on Human and Peoples' Rights, as a quasi-judicial body with a non-binding investigative and conciliation power, which may in certain circumstances also refer the case to the African Court on Human and Peoples' Rights. This court can decide on referred cases in a binding manner.

From the practice of the African Commission on Human and Peoples' Rights, the case concerning the protection of the right to environment, abbreviated as Ogoni v. Nigeria (2001), is already known. African Commission on Human and Peoples' Rights found that the Federal Republic of Nigeria violated e.g. Article 24 of the African Charter in this case.

This decision, for the first time in history, ruled directly that certain state violated substantive right to environment and ordered extensive environmental clean-up measures to be taken by this state. ${ }^{69}$ The African Charter is thus the only regional mechanism that allows direct access to environmental protection from the quasi-judicial authorities, but also from the international court.

Substantive human right to the environment can be protected, in the spirit of some rules of public international law, indirectly as well. The means of such indirect protection include, protection through procedural environmental rights included into some of the rules international environmental law, protection via

69 See BOER, Ben. Human Rights and the Environment: Where Next? In: BOER, Ben (ed.) Environmental Law Dimensions of Human Rights. Oxford: Oxford University Press, 2015. p. 224. 
extended interpretation of the scope of certain human rights anchored in the rules of international human rights law, protection by practical application of the other substantive environmental rights enshrined in international human rights law and protection by the rules of international environmental law itself.

The leading document in the area of indirect protection of right to environment through procedural environmental rights is abovementioned Aarhus Convention. The Aarhus Convention, in its Article 1, states as follows: „In order to contribute to the protection of the right of every person of present and future generations to live in an environment adequate to his or her health and wellbeing, each Party shall guarantee the rights of access to information, public participation in decision-making, and access to justice in environmental matters in accordance with the provisions of this Convention.".

The main goal of the Aarhus Convention to protect substantive right to environment through three procedural environmental rights - the right of access to environmental information, the right to participate in environmental decisionmaking and the right of access to legal protection in environmental matters, in accordance with the provisions of the Convention, and acts of national authorities in the field of application of their national rules. The Aarhus Convention provides, in its content, the necessary definitions, general provisions, detailed legal regulations for all three procedural environmental rights, and creates scope for the gradual completion of the Convention's controlling mechanisms, including mechanisms of communications from the public to the international authority in case of violation of these rights.

Some of international conventions on human rights enable indirect protection of right to environment by extended interpretation of the scope of certain human rights anchored inside those conventions by quasi-judicial or judicial organs created by those conventions. Such an opportunity provides for the jurisprudence of UN Human Rights Committee, European Court of Human Rights, Inter-American Commission on Human Rights, Inter-American Court of Human Rights etc.

Other way of indirect protection of right to environment is the protection by practical application of the other substantive environmental rights enshrined in international human rights law. Under the views of science of international public law there are two other substantive human environmental rights - right to water and right to sanitation. These rights are two distinct but closely related human rights. Both rights are anchored in many international conventions and documents. Formulation and protection of both substantive environmental rights clearly contribute to the protection of substantive right to environment, given the fact that it contributes to the protection of certain environmental dimensions protected by right to environment. 
Substantive human right to environment is indirectly protected by the rules of international environmental law itself, as well. International environmental law itself is clearly contributing to the protection of substantive human right to environment, given that it contributes to the protection of all environmental values protected in the scope of right to environment.

There are even mechanisms of direct and indirect protection of substantive right to environment in the scope of the European Union Law. However, analyzes of these mechanisms go beyond the scope of this article. ${ }^{70}$

\section{References}

ANTON, Donald, K., SHELTON, Dinah, L. Environmental Protection and Human Rights. Cambridge: Cambridge University Press, 2011. 1026 p. ISBN 978-0-521-74710-3.

Birnie, Patricia, W., Boyle, Alan, E. International Law and The Environment. Oxford: Oxford University Press, 1994. 563 p. ISBN 0-19-876283-6.

BIRNIE, Patricia, BOYLE, Alan, REDGWELL, Catherine. International Law and the Environment. Third Edition. New York: Oxford University Press 2009. 888 p. ISBN 978-0-19-876422-9.

BOER, Ben. Environmental Law and Human Rights in the Asia-Pacific. In: BOER, Ben (ed.). Environmental Law Dimensions of Human Rights. Oxford: Oxford University Press, 2015. pp. 135-180. ISBN 978-0-19-873614-1.

BOER, Ben. Human Rights and the Environment: Where Next? In: BOER, Ben (ed.). Environmental Law Dimensions of Human Rights. Oxford: Oxford University Press, 2015. pp. 201-239. ISBN 978-0-19-873614-1.

BOER, Ben (ed.). Environmental Law Dimensions of Human Rights. Oxford: Oxford University Press, 2015. 246 p. ISBN 978-0-19-873614-1.

CARLANE, Cinnamon, P., GRAY, Kevin, R., TARASOFSKY, Richard, G. The Oxford Handbook of International Climate Change Law. Oxford: Oxford University Press, 2016. 821 p. ISBN 978-0-19-968460-1.

CULLET, Philippe. Human Rights and Climate Change. Broadening the Right to Environment. In: CARLANE, Cinnamon, P. - GRAY, Kevin, R. - TARASOFSKY, Richard, G. The Oxford Handbook of International Climate Change Law. Oxford: Oxford University Press, 2016. p. 495-518. ISBN 978-0-19-968460-1.

COLLECTIVE OF AUTHORS. WaterLex. The Human Rights to Water and Sanitation: An Annotated Selection of International and Regional Law and Mechanisms. Geneva: WaterLex. 2017. 212 p. ISBN 978-2-940526-08-6.

70 To this problematics see JANKUV, J. Protection of Environmental Human Rights in the Scope of European Union Law. In: European Studies, Vol. 5, 2018. pp. 67-97. As to the protection of human rights in the scope of the European Union Law in general see HAMULÁK, O., RAMIRO TROITIÑO, D., CHOCHIA, A. Carta de los Derechos Fundamentales de la Unión Europea y los derechos sociales. In: Estudios Constitucionales, vol. 16, no. 1, 2018. pp. 167-186., HAMULÁK, O., MAZÁK J. The Charter of Fundamental Rights of the European Union vis-à-vis the Member States - Scope of its Application in the View of the CJEU. In: Czech Yearbook of Public \& Private International Law, vol. 8, 2017. pp. 161-172. and KERIKMÄE, T., HAMULÁK, O. CHOCHIA, A. A Historical Study of Contemporary Human Rights: Deviation or Extinction? In: Acta Baltica Historiae et Philosophiae Scientiarum, Vol. 4, No. 2, 2016. pp. 98-115. 
DAMOHORSKÝ, Milan et al. Mezinárodní právo životního prostředí, II. část (zvláštní). Beroun: Eva Rozkotová - IFEC, 2008. 318 p. ISBN 978-80-903409-8-9.

DÉJANT-PONS, Marguelonne, PALLEMAERTS, Marc. Human Rights and the Environment. Strasbourg: Council of Europe, 2002. 327 p. ISBN 92-871-4777-9.

HANDL, Günter. Human Rights and Protection of the Environment. In: EIDE, Asbjørn, KRAUSE, Catarina, ROSAS, Allan (eds.) Economic, Social and Cultural Rights. Leiden: Nijhoff, 2001. pp. 303-315. ISBN 0792332776.

HAMULÁK, O., RAMIRO TROITIÑO, D., CHOCHIA, A. Carta de los Derechos Fundamentales de la Unión Europea y los derechos sociales. In: Estudios Constitucionales, vol. 16, no. 1, 2018. pp. 167-186. ISSN 0718-0195 a

HAMULÁK, O., MAZÁK J. The Charter of Fundamental Rights of the European Union vis-à-vis the Member States - Scope of its Application in the View of the CJEU. In: Czech Yearbook of Public \& Private International Law, vol. 8, 2017. pp. 161-172, ISSN 1805-0565.

HARRIS, David, O‘Boyle, Michael, BATES, Ed, BUCKLEY, Carla. Harris, O‘Boyle, and Warbrick: Law of the European Convention on Human Rights. Fourth Edition. Oxford: Oxford University Press, 2018. 1056 p. ISBN 9780198785163.

HANNIKAINEN, Lauri. Legal Nature of Minority Rights as Part of Human Rights, Limitations, Derogations, Reservations, and Interpretative statements. In: WELLER, Marc (ed). Universal Minority Rights, A Commentary on the Jurisprudence of International Courts and Treaty Bodies. Oxford: Oxford University Press, 2007. p. 27-48. ISBN 9780-19-920851-7.

JANKUV, Juraj. Mechanizmy ochrany ludských environmentálnych práv v medzinárodnom práve verejnom, $v$ práve európskej únie a v právnom poriadku Slovenskej republiky. Praha: Leges. 2018. 200 p. ISBN 978-80-7502-309-4.

JANKUV, Juraj. Ludské právo na životné prostredie a mechanizmy jeho ochrany v medzinárodnom práve. In: Acta Universitatis Carolinae - Iuridica, Praha, č. 4, 2006 (issued in 2008). pp. 63-83. ISSN 0323-0619.

JANKUV, J. Protection of Environmental Human Rights in the Scope of European Union Law. In: European Studies, Vol. 5, 2018. pp. 67-97. ISSN 1805-8809.

JANKUV, Juraj, LANTAJOVÁ, Dagmar, BLAŠKOVIČ, Kristián, BUCHTA, Tomáš, ARBET, Daniel. Medzinárodné právo verejné. Druhá čast'. Plzeň: Aleš Čeněk, 2016. 463 p. ISBN 978-80-7380-597-5.

KERIKMÄE, T., HAMULÁK, O. CHOCHIA, A. A Historical Study of Contemporary Human Rights: Deviation or Extinction? In: Acta Baltica Historiae et Philosophiae Scientiarum, Vol. 4, No. 2, 2016. pp. 98-115. ISSN 2228-2009.

KISS, Alexandre. Le droit á lenvironment en tant que moyen d'assurer la mise en oeuvre de traités internationaux. In: Šturma, Pavel (ed.) et al. Implementation and Enforcement of International Environmental Law. Praha: Univerzita Karlova, 2002. pp. 38-45. ISBN 80-85889-45-5.

KLUČKA, Ján. Medzinárodné právo verejné (Všeobecná a osobitná čast'). Bratislava: Wolters Kluwer, 2017. pp. 79-80. ISBN 978-80-8168-743-3.

KOŠIČIAROVÁ, Soňa a kol. Právo životného prostredia. Žilina: Eurokódex, 2006. 463 p. ISBN 80-88931-57-6.

LOUKA, Eli. International Environmental Law. Fairness, Effectiveness, and World Order. Cambridge: Cambridge University Press, 2006. 518 p. ISBN 978-0-511-24967-9.

MASLEN, Michal. Právna úprava starostlivosti o vody v Slovenskej republike. Praha: Leges, 2017. pp. 10-11. ISBN 978-80-7502-193-9. 
MASLEN, Michal. Verejná správa a právo na životné prostredie. Praha: Leges, 2016. 248 p. ISBN 978-80-7502-198-4.

MCGOLDRICK, Dominic. The Human Rights Committee. Oxford: Clarendon Press, 1994. 648 p. ISBN 978-01-9825-894-0.

ONDŘEJ, Jan. Mezinárodněprávní ochrana životního prostředí na konci 20. století. In: Acta Universitatis Carolinae-Iuridica, č. 3-4/1998. pp. 77-79. ISSN 0323-0619, ISBN 80-7184-879-4.

PAVONI, Riccardo. Environmental Jurisprudence of the European and Inter - American Courts of Human Rights. In: BOER, Ben (ed.). Environmental Law Dimensions of Human Rights. Oxford: Oxford University Press, 2015. pp. 69-108. ISBN 978-0-19873614-1.

POTOČNÝ, Miroslav, ONDǨEJ, Jan. Mezinárodní právo veřejné. Zvláštní část. 6. doplnèné a prepracované vydání. Praha: C. H. Beck 2011. 556 p. ISBN 978-80-7400-398-1.

RIVERA - RODRIGUEZ, Luis E. Is the Human Right to Environment Recognized under International Law? In: Colorado Journal of International Environmental Law and Policy, Vol. 12, No.1, (2001) pp. 31-37. ISSN 1050-0391.

SANDS, Philippe, PEEL, Jacqueline, FABRA, Adriana, MACKENZIE, Ruth. Principles of International Environmental Law. Third Edition. Cambridge: Cambridge University Press, 2012. 926 p. ISBN 978-0-521-14093-5.

SHAW, Malcolm, N. International Law. Sixth Edition. Cambridge: Cambridge University Press, 2008. 1708 p. ISBN 978-0-521-72814-0.

SHELTON, Dinah. Human Rights and the Environment: What specific Environmental Rights Have Been Recognized? In: Denver Journal of International Law and Policy. Vol. 35, No.1, 2006. pp. 129-171. ISSN 0196-2035.

STRÁŽNICKÁ, Viera et al. Medzinárodná a európska ochrana ludských práv. Žilina: Eurokódex, 2013. 551 p. ISBN 978-80-89447-95-4.

SVÁK, Ján. Ochrana ludských práv ( $z$ pohladu judikatúry a doktriny štrasburských orgánov ochrany práv). II. rozšírené vydanie. Žilina: Eurokódex 2006. 1116 p. ISBN 80-8893151-7.

ŠTURMA, Pavel. Mezinárodní a evropské kontrolní mechanismy v oblasti lidských práv. 3.doplněné vydání. Praha: C. H. Beck, 2010. 170 p. ISBN 978-80-7400-318-9.

ŠTURMA, Pavel. Mezinárodní odpovědnost za škody v mezinárodním právu životního prostředí. In.: Šturma, Pavel et al. Mezinárodní právo životního prostředí, I.část (obecná). Beroun: Eva Rozkotová-IFEC, 2004. pp. 116-158. ISBN 80-903409-2-X.

ŠTURMA, Pavel et al. Mezinárodní právo životního prostředí, I. část (obecná). Beroun: Eva Rozkotová-IFEC, 2004. 193 p. ISBN 80-903409-2-X.

TAVERNIER, Paul. La Cour européene des droits de l' Homme et la mise en oeuvre du droit international de lenvironment. In: Šturma, Pavel et al. Implementation and Enforcement of International Environmental Law. Praha: Univerzita Karlova, 2002. pp. 47-60. ISBN 80-85889-45-5.

VRŠANSKÝ, Peter, VALUCH. Jozef et al. Medzinárodné právo verejné. Osobitná čast'. Bratislava: Eurokódex, 2013. 544 p. ISBN 978-80-8155-003-4.

WELLER, Marc (ed). Universal Minority Rights, A Commentary on the Jurisprudence of International Courts and Treaty Bodies. Oxford University Press, 2007. 525 p. ISBN 978-0-19-920851-7.

ZÁSTĚROVÁ, Jana. Jednotlivci: právo na životní prostředí (kapitola v učebnici), In: ŠTURMA, P. et al. Mezinárodní právo životního prostredí, I. část (obecná). Beroun: Eva Rozkotová-IFEC, 2004. pp. 35-57. ISBN 80-903409-2-X. 